\title{
Population dynamics and stock assessment of grey sharpnose shark Rhizoprionodon oligolinx Springer, 1964 (Chondrichthyes: Carcharhinidae) from the north-west coast of India
}

\author{
G. B. PURUSHOTTAMA ${ }^{1}$, GYANARANJAN DASH ${ }^{2}$, THAKURDAS ${ }^{3}$, K. V. AKHILESH ${ }^{3}$, \\ SHOBA JOE KIZHAKUDAN ${ }^{4}$ AND P. U. ZACHARIA ${ }^{5}$ \\ ${ }^{1}$ Mangalore Research Centre of ICAR-Central Marine Fisheries Research Institute, P. B. No. 244, Hoige Bazar \\ Mangaluru - 575 001, Karnataka, India \\ ${ }^{2}$ Digha Research Centre of ICAR-Central Marine Fisheries Research Institute, Digha - 721 441, West Bengal, India \\ ${ }^{3}$ Mumbai Research Centre of ICAR-Central Marine Fisheries Research Institute, Mumbai - 400 061, Maharashtra, India \\ ${ }^{4}$ Madras Research Centre of ICAR-Central Marine Fisheries Research Institute, Chennai - 600 028, Tamil Nadu, India \\ ${ }^{5}$ ICAR-Central Marine Fisheries Research Institute, P. O. Box 1603, Ernakulam North, P. O., Kochi - 682 018, Kerala, India \\ e-mail:puru44@gmail.com
}

\begin{abstract}
The life history and exploitation parameters of Rhizoprionodon oligolinx Springer, 1964 were assessed using commercial landing data of 2012-2015 from Mumbai waters of India to understand the population dynamics and stock status of the species. The average annual landing of the species was estimated to be $383 \mathrm{t}$, which formed about $9.1 \%$ of the total shark landings of Maharashtra. $\mathrm{L}_{\infty} \mathrm{K}$ and $\mathrm{t}_{0}$ estimated were $97.1 \mathrm{~cm}, 0.47 \mathrm{yr}^{-1}$ and $-0.79 \mathrm{yr}$ respectively. Total mortality (Z), fishing mortality (F) and natural mortality (M) rates were estimated as $2.16 \mathrm{yr}^{-1}, 1.48 \mathrm{yr}^{-1}$ and $0.69 \mathrm{yr}^{-1}$ respectively. The length at capture $\left(\mathrm{L}_{50}\right)$, length at female maturity $\left(\mathrm{Lm}_{50}\right)$ and male maturity $\left(\mathrm{Lm}_{50}\right)$ were estimated as $49.7,62.3$ and $59.5 \mathrm{~cm}$ respectively, which indicated that most of the sharks entered peak phase of exploitation before attaining sexual maturity. Length-weight relationship indicated allometric growth $(b>3)$ for the species. The species was found to be a continuous breeder and showed peak recruitment during April. The current exploitation rate $\left(\mathrm{E}_{\text {cur }}\right)$ was found to be 0.68 , which is lower than $\mathrm{E}_{\max }$ estimated for the species using Beverton and Holt yield per recruit analysis. Thompson and Bell prediction model showed that at current exploitation level, the biomass (B) has reduced to $32 \%$ of virgin biomass (B0) where as, the spawning stock biomass (SSB) has reduced to $16 \%$ of the virgin spawning stock biomass (SSB0). Hence the exploitation level for the species should be reduced by $40 \%$ that will ensure the availability of SSB at a relatively safer $30 \%$ level to rebuild the stock for long term sustainability of the resource.
\end{abstract}

Keywords: Grey sharpnose shark, Growth parameters, Length-weight relationship, Maturity, Spawning stock biomass

\section{Introduction}

In the past there was no organised shark fishery in India and sharks were caught incidentally and formed bycatch in the gears. Till late 1960s (pre trawl period) the shark fishery was more or less neglected and the resource was not adequately studied for the reason that the shark flesh was less preferred as an edible meat owing to its pungent odour caused by the presence of trimethylamine. The rapid expansion of fisheries and globalised trade have emerged as the principal drivers of shark fishing to meet the rising demand for their meat, fins, liver and other products. This has led to indiscriminate fishing of the resource which is decimating their population as a result of which the global shark catch is in a declining phase (Bonfil, 1994; Hanfee, 1999, 2001; Vivekanandan, 2001).
The state of Maharashtra (19³9' $47.8080^{\prime \prime} \mathrm{N} ; 75^{\circ} 18^{\prime}$ 1.0548 " E) along the west coast of India is endowed with a $720 \mathrm{~km}$ long coastline and harbours rich elasmobranch diversity (Raje et al., 2002). The total number of elasmobranch species in Maharashtra is estimated to be 76 of which $3.8 \%$ are listed as Critically Endangered (CR), 5\% as Endangered (EN), 25.2\% Vulnerable (VU), $20.8 \%$ Near Threatened (NT), $8.8 \%$ of Least Concern (LC), $26.4 \%$ as Data Deficient (DD) and $10.1 \%$ as Not Evaluated (NE) (Purushottama et al., in press).

A few species of small/medium coastal sharks are caught regularly in targeted fisheries and as bycatch in waters off Maharashtra. The group presently includes the spadenose shark (Scoliodon laticaudus), grey sharpnose shark (Rhizoprionodon oligolinx), milk shark (Rhizoprionodon acutus), spot-tail shark (Carcharhinus 
sorrah), whitecheek shark (Carcharhinus dussumeiri) and hardnose shark (Carcharhinus macloti). Elasmobranch landing statistics for Maharashtra during the period 2012 to 2015 shows that among sharks, the landing was mainly contributed by $S$. laticaudus (72.5\%) followed by $R$. oligolinx $(9.1 \%)$. Apart from this, a major contribution was also made by $R$. acutus $(3.8 \%)$, Lamiopsis temminckii (3.1\%), Sphyrna lewini (2.2\%), C. macloti (1.8\%), Carcharhinus limbatus (1.5\%), C. sorrah (1.0\%), Carcharhinus leucas (0.5\%), Carcharhinus amblyrhynchoides (0.4\%), Galeocerdo cuvier $(0.1 \%)$ and other sharks $(3.9 \%)$. The sharks were mainly exploited by gillnetters (44.9\%), trawlers (42.7\%), dol netters $(8.7 \%)$ and other gears $(3.7 \%)$ in Maharashtra (CMFRI, 2013; 2014; 2015; 2016).

Of the seven species of the genus Rhizoprionodon Whitley, 1929, only two species $R$. acutus and $R$. oligolinx are known from the Arabian Sea (Ebert et al., 2013). Rhizoprionodon spp. are identified by their long upper labial furrow and the second dorsal fin origin posterior to the origin of the anal and pre-anal ridges (Compagno, 1984; Compagno et al., 2005). Elasmobranchs are mostly characterised by slow growth, large size, late maturity and production of few off-springs which is known as $\mathrm{K}$ selected life history strategy, which makes them vulnerable to fishing, with low generation turnover rates (Holden, 1974; Jennings et al., 1998; Ebert et al., 2008). High fishing mortality coupled with juvenile discards have already depleted some species, while endangering others (Stevens et al., 2000).

$R$. oligolinx is a commercially important shark in Maharashtra and is used both domestically and for export. When landed in large quantities, a portion is marketed in fresh condition owing to demand for fresh meat, a larger portion is processed for its high-quality meat, by filleting and salting and sold in local markets or traded to nearby regions/states where there is a high demand for salted meat. Majority of salted shark meat $(60 \%)$ are sold to merchants/agents from the southern states of India like Andhra Pradesh, Karnataka, Kerala, Tamil Nadu as well as Telangana. Nearly $40 \%$ of salted shark meat and products are exported to Sri Lanka and Nepal. The liver of these sharks are removed and the oil is extracted along with other common shark species occurring in the region viz., $R$. acutus, S. laticaudus, C. macloti, L. temminckii and $C$. sorrah. However, since the resulting oil is of low quality, it is mostly used for the painting of wooden fishing boats as antifouling agent or used for local medicinal purposes. The fins (dorsal, pectoral and caudal) fetch good value ranging from USD 10-14 per $\mathrm{kg}$.

Detailed study on the exploitation level and stock status of $R$. oligolinx is scarce in the region and elsewhere.
Therefore, the present study was carried out to assess the exploitation and stock status of the species so that proper management advisory can be formulated to maintain the resilience of the species and sustainable harvest of the resource.

\section{Materials and methods}

Weekly data on catch and effort of fish landed in all major fish landing centres in different districts of Maharashtra was collected and raised to monthly and annual figures using the Stratified Random Sampling Technique (Alagaraja, 1984). Using the data of National Marine Living Resource Data Centre (NMLRDC) of ICAR-Central Marine Fisheireis Research Institute (ICAR-CMFRI), Kochi, the marine fish catch trends of the state was analysed for the period from 1996 to 2015. Data on length frequency of $R$. oligolinx was collected for 4 years during January 2012 to December 2015 at weekly intervals from Satpati, Sassoon Dock and New Ferry Wharf fish landing centres of Maharashtra (Fig.1). Total length (TL), length between tips of the snout to the posterior margin of upper caudal fin across the middle line were measured for each shark to the nearest $\mathrm{cm}$ using a measuring tape and the body weight (BW) was recorded to the nearest $\mathrm{g}$ using an electronic weighing machine (Axpert, India). A total of 711 fresh specimens of $R$. oligolinx in the size range 36.4 to $93.0 \mathrm{~cm}$ TL and weight range 200 to $2600 \mathrm{~g}$ for females and length range 34.5 to $93.0 \mathrm{~cm}$ TL and weight range 200 to $2100 \mathrm{~g}$ for males were collected randomly for analysis. The von Bertalanffy's growth parameters (von Bertalanffy, 1938) viz., asymptotic length $\left(\mathrm{L}_{\infty}\right)$ and growth co-efficient (K) were estimated using monthly raised data in the ELEFAN-I module of FiSAT II (Gayanilo et al., 2005). Age at length zero $\left(\mathrm{t}_{0}\right)$ was back calculated using modified von Bertalanffy's growth equation i.e. $\mathrm{t}_{0}=1 / \mathrm{K} \log _{\mathrm{e}}\left[1-\left(\mathrm{L}_{\mathrm{t}=0}\right.\right.$ $\left./ \mathrm{L}_{\infty}\right)$ ]. For calculation of $\mathrm{t}_{\mathrm{o}}, 30 \mathrm{~cm}$ was used as length at birth $\left(\mathrm{L}_{\mathrm{t}=0}\right)$ which was assumed from length of the smallest free-swimming individuals observed from the fishery. The modal class progression analysis (MPA) was also carried out to refine the growth parameters obtained from ELEFAN-I following Bhattacharya's method. A range of $\mathrm{k}\left(0.2\right.$ to $\left.0.6 \mathrm{yr}^{-1}\right)$ were used in the iteration to fit the growth curve using the 'length at age data' generated from MPA analysis. The $\mathrm{L}_{\mathrm{t}=0}$ as $30 \mathrm{~cm}$ and $\mathrm{t}_{0}$ of about $1 \mathrm{yr}$ was used as the yardstick to select the most reasonable growth curve for the species. The growth performance index $(\varphi)$ was calculated from formula as described by Pauly and Munro (1984) i.e., $\varphi=\log _{10} \mathrm{~K}+2 \log _{10} \mathrm{~L}_{\infty}$. Longevity $\left(\mathrm{t}_{\max }\right)$ was estimated from the equation described by Pauly (1983) i.e., $\mathrm{t}_{\max }=3 / \mathrm{K}+\mathrm{t}_{0}$. The length-weight relationship of $R$. oligolinx was established following the formula, $\mathrm{W}=\mathrm{aL}^{\mathrm{b}}$ (Le Cren, 1951). After logarithmic transformation 


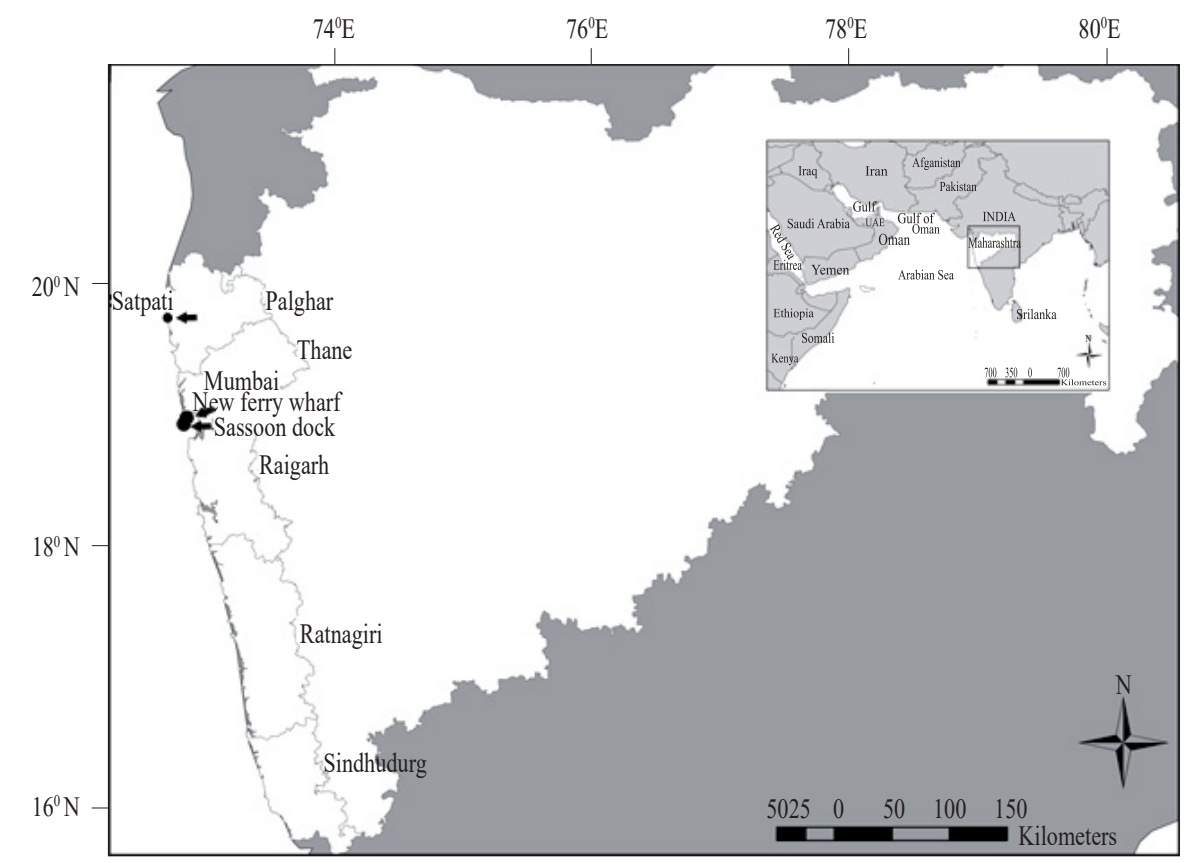

Fig. 1. Map of Maharashtra showing locations where the specimens of R. oligolinx were landed and an inset depicting political boundaries

of length and weight data, this equation may be expressed as: $\log W=\log a+b \log L$, where, $W$ is the weight of the fish in grams, $L$ is the total length of the shark in $\mathrm{cm}, a$ is the intercept of the regression curve (coefficient related to body form) and $b$ is the regression coefficient (exponent indicating isometric growth; Froese, 2006).

The instantaneous total mortality rate $(Z)$ was estimated by FiSAT II package using the length converted catch curve method (Pauly, 1983). The natural mortality rate (M) was estimated by Pauly's (1983) empirical formula, $\ln (\mathrm{M})=-0.0152-0.279 \ln \left(\mathrm{L}_{\infty}\right)+0.6543 \ln (\mathrm{K})+$ $0.463 \ln (\mathrm{T})$ and the fishing mortality rate $(\mathrm{F})$ was obtained as $\mathrm{F}=\mathrm{Z}-\mathrm{M}$. The current exploitation rate $\left(\mathrm{E}_{\text {cur }}\right)$ was calculated as $E=F / Z$ (Ricker, 1975). Length structured cohort analysis (VPA) of FiSAT II was used to obtain fishing mortalities per length class.

For determining Length at first maturity $\left(\mathrm{Lm}_{50}\right)$, a total of 663 (females $=369$; males $=294$ ) specimens were used. The maturity status of each shark was ascertained following the classification scheme proposed by Stehmann (2002), based on ovarian and uterine condition for females and clasper calcification and testes development for males. The $\mathrm{Lm}_{50}$ was calculated using the logistic regression described by White (2007) as follows:

$$
\mathrm{pL}=\left[1+6\left\{-\operatorname{In}(19)\left(\mathrm{L}_{-} \mathrm{Lm}_{50}\right)\left(\mathrm{L}_{95}-\mathrm{Lm}_{50}\right)^{-1}\right\}\right]^{-1}
$$

where, $\mathrm{pL}$ is the proportion of sharks that are matured at length $\mathrm{L} ; \mathrm{Lm}_{50}$ and $\mathrm{Lm}_{95}$ are the lengths at which 50 and $95 \%$ sharks in the stock are matured. The SOLVER routine in Microsoft ${ }^{\mathrm{TM}}$ Excel was used to obtain maximum likelihood estimates of the parameters.

The recruitment pattern of the stock was determined by backward projection on the length axis of the set of available length frequency data as described in FiSAT II (Pauly and Caddy, 1985). The midpoint of the smallest length group in the catch during the four year period was taken as length at recruitment $\left(\mathrm{L}_{\mathrm{r}}\right)$. Length at first capture $\left(\mathrm{L}_{50}\right)$ was estimated by probability of capture routine in the FiSAT-II package (Pauly, 1987). The probability of capture of sequential length classes were regressed using a logit curve for the estimation of $\mathrm{L}_{50}$.

The relative yield per recruit $\left(\mathrm{Y}^{\prime} / \mathrm{R}\right)$ and relative biomass per recruit (B'/R) at different exploitation levels were estimated by FiSAT II package using relative yield per recruit analysis method as described by Beverton and Holt (1966). The equilibrium yield such as catch (Y) and revenue (INR), standing stock biomass (B) and spawning stock biomass (SSB) at different fishing levels were predicted using length based Thompson and Bell bio-economic model (Thompson and Bell, 1934). The data from above stock assessment models were used to forecast the biological reference points (BRPs) for the sustainable exploitation of the grey shapnose shark resource.

\section{Results and discussion}

Fisheries and utilisation

The marine fish landing scenario of Maharashtra was analysed for the last two decades and it revealed that 
landings marginally decreased by 0.8 times from an annual average of 3,70,385 $\mathrm{t}$ during $1996-2005$ to $3,14,548 \mathrm{t}$ during 2006 to 2015 . The contribution of shark landings to the total marine fish landings marginally fluctuated on an average from $1.9 \%$ (7,085 t) during 1996-2005 to $1.7 \%(5,311 \mathrm{t})$ during 2006-2015. Shark catch in the state peaked at 14,186 $\mathrm{t}$ in 2002 and fell to 3,441 $\mathrm{t}$ in 2010.

$R$. oligolinx recorded during the study period were landed by mechanised gillnetters (18-20 m OAL) operating monofilament gillnet [70-100 m length (70-100 pieces), mesh size $90-110 \mathrm{~mm}$ ] and multifilament gillnet $[70 \mathrm{~m}$ length (50-60 pieces), mesh size: $80-110 \mathrm{~mm}$ ] targeting pomfrets, seerfish and elasmobranchs at $40-50 \mathrm{~m}$ depth off north-west coast of India. Another variant of the gillnet (70 m length, mesh size: $220-270 \mathrm{~mm}$ ) was exclusively employed for catching elasmobranchs, polynemids, large sciaenids and eels during December to May.

The estimated annual landings (2009-2015) of $R$. oligolinx in Maharashtra by gillnets ranged from $109 \mathrm{t}$ in 2012 to $543 \mathrm{t}$ in 2013 . There was a $39 \%(2.4$ times) increase in landings in 2015 compared to 2012. The catch and effort of gillnets from Maharashtra during 2012-2015 is given in Table 1. Landings of R. oligolinx in Maharashtra varied considerably across years and months with the greatest landings recorded in April 2013 during the study period (167 t, because of the high level targeted gillnet fishery and availability of sharks in the fishing grounds), followed by March 2013 (35.9 t), April 2015 (62 t), December 2013 (60.4 t) and September 2014 (49.5 t) (Fig. 2).

\section{Stock structure}

A total of 711 sharks were collected for the study of which females constituted 55.7\% $(n=369)$ and males $44.3 \%(n=294)$ with an overall sex ratio (male: female) of 1:1.2 and 48 unsexed specimens (Fig. 3). $R$. oligolinx females ranged from 36.4 to $93.0 \mathrm{~cm}$ TL $($ mean \pm S.E. $=68.0 \pm 0.3$ ) and 200 to $2600 \mathrm{~g}$ in total weight $($ mean \pm S.E. $=1520.2 \pm 21.8)$. Males ranged from 34.5 to $93.0 \mathrm{~cm} \mathrm{TL}($ mean \pm S.E. $=62.4 \pm 0.4)$ and 200 to 2100 $\mathrm{g}$ in total weight $(\operatorname{mean} \pm$ S.E. $=1082.6 \pm 14.7)$. The $\chi^{2}$ test revealed significant differences $(p<0.001)$ in length frequency distributions between females and males, with more females between 66 and $70 \mathrm{~cm}$ TL and more males for the 61-65 cm TL size class. The size range of $R$. oligolinx observed in the gillnet fishery of Maharashtra (27.0-93.0 cm TL) differs slightly from those reported from other regions by Moore et al. (2012) in Kuwait waters $(45-85 \mathrm{~cm}$ TL for females and 45-64 $\mathrm{cm}$ TL for

Table 1. Catch and effort of R. oligolinx in gillnet from Maharashtra coast of India during 2012-2015

\begin{tabular}{|c|c|c|c|c|c|c|c|c|}
\hline \multirow{2}{*}{ Year } & \multirow{2}{*}{$\begin{array}{l}\text { Effort } \\
\text { (h) }\end{array}$} & \multirow{2}{*}{$\begin{array}{l}\text { Total marine } \\
\text { landings }(\mathrm{t})\end{array}$} & \multirow{2}{*}{$\begin{array}{l}\text { Elasmobranch } \\
\text { landings }(\mathrm{t})\end{array}$} & \multirow{2}{*}{$\begin{array}{l}\text { Total commercial } \\
\text { shark landing }(\mathrm{t})\end{array}$} & \multirow{2}{*}{$\begin{array}{l}\text { Percentage of shark } \\
\text { landing to total } \\
\text { marine landing }\end{array}$} & \multicolumn{3}{|c|}{ Rhizoprionodon oligolinx } \\
\hline & & & & & & $\begin{array}{l}\text { Catch } \\
(\mathrm{t})\end{array}$ & $\begin{array}{l}\mathrm{CPH} \\
\left(\mathrm{kg} \mathrm{h}^{-1}\right)\end{array}$ & $\begin{array}{l}\% \text { to total } \\
\text { shark landing }\end{array}$ \\
\hline 2012 & $1,45,9431$ & $3,14,834$ & 4,159 & 3,889 & 1.2 & 109 & 0.075 & 2.8 \\
\hline 2013 & $2,26,7515$ & $3,64,340$ & 5,476 & 4,550 & 1.2 & 543 & 0.24 & 11.9 \\
\hline 2014 & $2,47,4190$ & $3,44,648$ & 5,779 & 4,780 & 1.4 & 237 & 0.096 & 4.9 \\
\hline 2015 & $2,07,8132$ & $2,64,891$ & 4,474 & 3,548 & 1.3 & 258 & 0.12 & 7.3 \\
\hline Average & $2,06,9817$ & $3,22,178$ & 5,062 & 4,192 & 1.3 & 287 & 0.13 & 6.7 \\
\hline
\end{tabular}

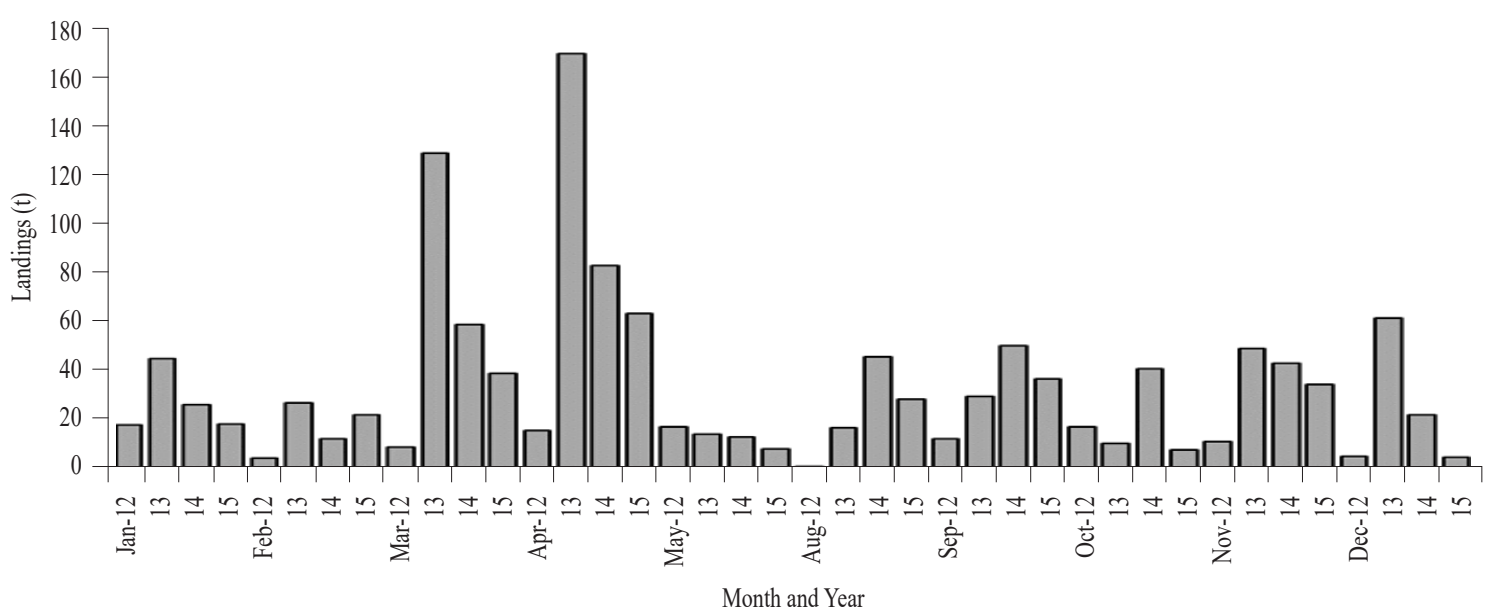

Fig. 2. Monthly estimated landings of R. oligolinx in gillnet along Maharashtra from January 2012 to December 2015 (Mechanised fishing ban/closed season was observed during June and July along the west coast of India) 


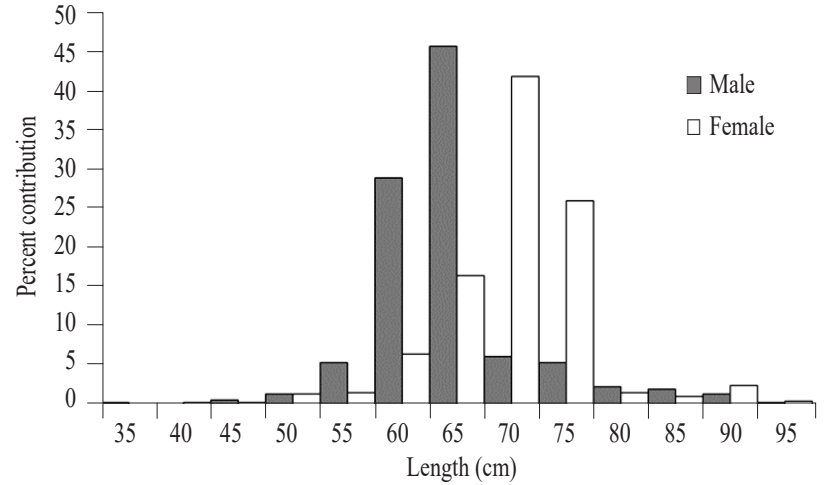

Fig. 3. Total length (TL)-frequency histogram of Rhizoprionodon oligolinx [Female $(n=369)$; males $(n=294)$ ] along Maharashtra coast

males) and White (2007) in Indonesian waters (26-65 cm TL for females, 29.5-52.0 cm TL for males).

Growth, mortality and exploitation parameters

The $\mathrm{L}_{\infty}$ and $\mathrm{K}$ as estimated by ELEFAN-I were $97.13 \mathrm{~cm}$ and $0.47 \mathrm{yr}^{-1}$ (Table 2, Fig. 4) which resulted in $\mathrm{a} \mathrm{t}_{0}$ of $-0.79 \mathrm{yr}$. The MPA using $\mathrm{k}$ in the range of 0.2 to $0.6 \mathrm{yr}^{-1}$ resulted in $\mathrm{L}_{\infty}$ values from 91.5 to $138.5 \mathrm{~cm}$ and corresponding $t_{0}$ values from -1.3 to $-0.63 \mathrm{yr}^{-1}$ (Fig. 5). The $\mathrm{L}_{\infty}$ and $\mathrm{K}$ values of $106.9 \mathrm{~cm}$ and $-0.4 \mathrm{yr}^{-1}$ respectively, obtained using $\mathrm{t}_{0}$ of $-0.89 \mathrm{yr}$ in MPA were selected as the most appropriate estimates of growth parameters (Fig. 6) as the modeled length at birth $\left(\mathrm{L}_{\mathrm{t}=0}\right)$ of $30 \mathrm{~cm}$ obtained using these growth parameters was same as that of the observed $\mathrm{L}_{t=0}$. The growth curve constructed using von Berttalanffy's growth (VBG) parameters showed that the shark grows to a TL of $54.8 \mathrm{~cm}$ in $1^{\text {st }} \mathrm{yr}, 71.5 \mathrm{~cm}$ in $2^{\text {nd }} \mathrm{yr}, 82.7 \mathrm{~cm}$ in $3^{\text {rd }} \mathrm{yr}$, after which the growth slows down considerably registering a TL of $90.2 \mathrm{~cm}$ in $4^{\text {th }}$ year, $95.2 \mathrm{~cm}$ in $5^{\text {th }} \mathrm{yr}, 98.6 \mathrm{~cm}$ in $6^{\text {th }} \mathrm{yr}$ and $100.9 \mathrm{~cm}$ in $7^{\text {th }}$ year (Fig. 5). The growth performance index and $t_{\text {max }}$ of the species was found to be 3.65 and $6.6 \mathrm{yr}$ respectively. Since direct estimation of $\mathrm{L}_{\mathrm{t}=0}$ was beyond the scope of present study, the largest embryo size and smallest free swimming individuals

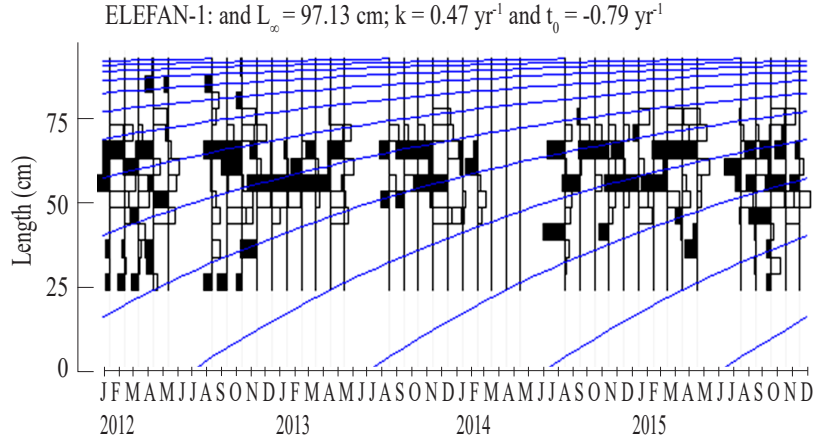

Fig. 4. von Bertalanffy's equation fitted growth curve of $R$. oligolinx using ELEFAN-I

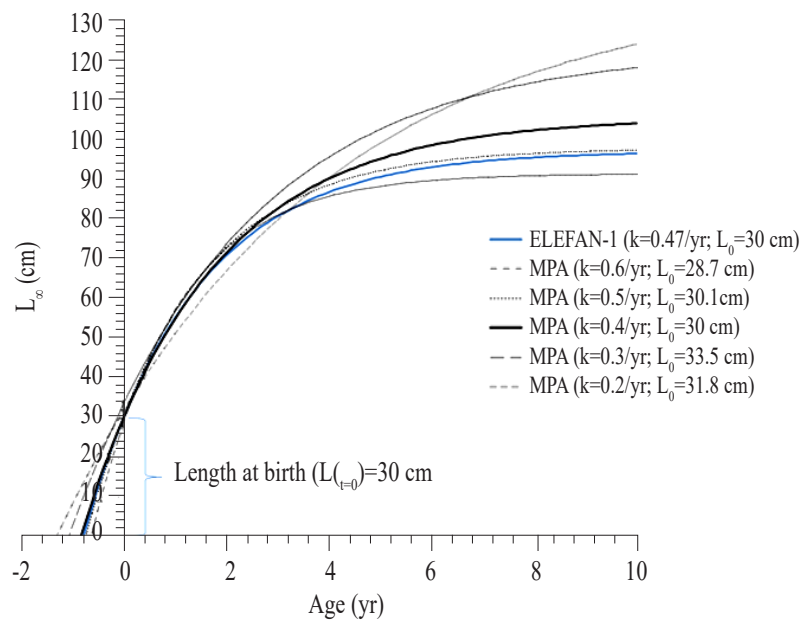

Fig. 5. Comparision of reconstructed VBGF growth curve fitted using growth parameters obtained from ELEFAN-I and MPA

were used to ascertain the $\mathrm{L}_{\mathrm{t}=0}$. The length at birth $\left(\mathrm{L}_{\mathrm{t}=0}\right)$ in the present study was estimated as $30 \mathrm{~cm}$. This is found to be close to that of $R$. acutus in the same genus, where $\mathrm{L}_{\mathrm{t}=0}$ has been mentioned as $30 \mathrm{~cm}$ from south-east and north-west coasts of India (Krishnamoorty and Jagadish, 1986; Sen et al., 2017). The maximum length $\left(\mathrm{L}_{\max }=93.0 \mathrm{~cm}\right)$ observed in the present study was, however, found to be higher than the earlier reported length of $85.0 \mathrm{~cm}$ TL from Kuwait waters (Moore et al.,

Table 2. Growth parameters of R. oligolinx from Maharashtra coast of India during 2012-2015

\begin{tabular}{lllllll}
\hline \multirow{2}{*}{$\begin{array}{l}\text { von Bertalanffy's } \\
\text { Growth parameters }\end{array}$} & $\begin{array}{l}\text { ELEFAN-I } \\
\mathrm{k}=0.47\left(\mathrm{yr}^{-1}\right)\end{array}$ & $\mathrm{k}=0.2\left(\mathrm{yr}^{-1}\right)$ & $\mathrm{k}=0.3\left(\mathrm{yr}^{-1}\right)$ & $\mathrm{k}=0.4\left(\mathrm{yr}^{-1}\right)$ & $\mathrm{k}=0.5\left(\mathrm{yr}^{-1}\right)$ & $\mathrm{k}=0.6\left(\mathrm{yr}^{-1}\right)$ \\
\hline $\mathrm{L}_{\infty}(\mathrm{cm})$ & 97.13 & 138.50 & 122.56 & 105.50 & 97.84 & 91.48 \\
$\mathrm{t}_{0}(\mathrm{yr})$ & -0.79 & -1.30 & -1.06 & -0.84 & -0.74 & -0.63 \\
VBGF fitted $\mathrm{L}_{0}(\mathrm{~cm})$ & 30.0 & 31.8 & 33.5 & 30.0 & 30.2 & 28.7 \\
$\mathrm{~T}_{\max }$ & 5.59 & 13.70 & 8.94 & 6.66 & 5.26 & 4.37 \\
\hline
\end{tabular}

ELEFAN-I: Electronic Length Frequency Analysis-I method; MPA: Modal class progression analysis method; VBGF: von Bertalanffy's growth curve (equation); $\mathrm{L}_{\infty}$ : Maximum theoretical length the animal can reach; $\mathrm{K}$ : curvature parameter; $\mathrm{t}_{0}$ : Time when length of the animal is theoretically zero; $\mathrm{L}_{\mathrm{t}=0}$. Length of the animal at birth 


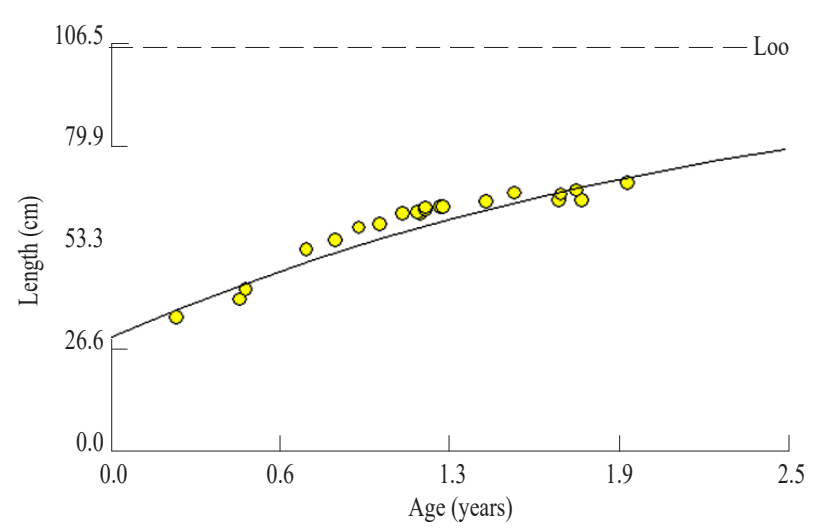

Fig. 6. Modal class progression analysis (MPA) growth curve obtained using length at age data by decomposing cohorts in Bhattacharya's method

2012) and $65.0 \mathrm{~cm}$ TL in Indonesian waters (White, 2007). The growth performance index $(\varphi)$ and longevity obtained in the present study were 3.65 and $6.6 \mathrm{yr}$ respectively, which indicate that the estimation of $\mathrm{L}_{\infty}$ and $\mathrm{K}$ is realistic (Compagno, 1984).

The natural mortality rate $(\mathrm{M})$, total mortality rate $(\mathrm{Z})$, fishing mortality rate $(\mathrm{F})$ and current exploitation rate $\left(\mathrm{E}_{\text {cur }}\right)$ were found to be $0.69 \mathrm{yr}^{-1}, 2.16 \mathrm{yr}^{-1}, 1.48 \mathrm{yr}^{-1}$ and 0.68 respectively (Fig. 7). The Length based cohort analysis showed that $\mathrm{F}$ exceeded $\mathrm{M}$ when the shark attains $55 \mathrm{~cm}$ TL (Fig. 8).

\section{Length-weight relationship}

The length-weight relationship for different groups (male, female and pooled data) is given below:

$$
\begin{aligned}
& \text { Females : } \mathrm{W}=0.000717663 \times \mathrm{TL}^{3.466747}\left(\mathrm{R}^{2}=0.909, n=279\right) \\
& \text { Males }: \mathrm{W}=0.015313967 \times \mathrm{TL}^{2.709603}\left(\mathrm{R}^{2}=0.907, n=186\right) \\
& \text { Pooled }: \mathrm{W}=0.00102409 \times \mathrm{TL}^{3.377588}\left(\mathrm{R}^{2}=0.924, n=465\right)
\end{aligned}
$$

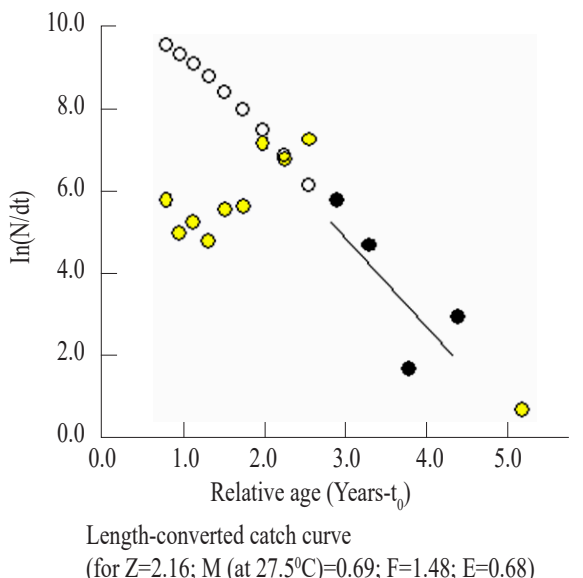

Fig. 7. Mortality parameters viz. M. F, Z and E of Rhizoprionodon oligolinx

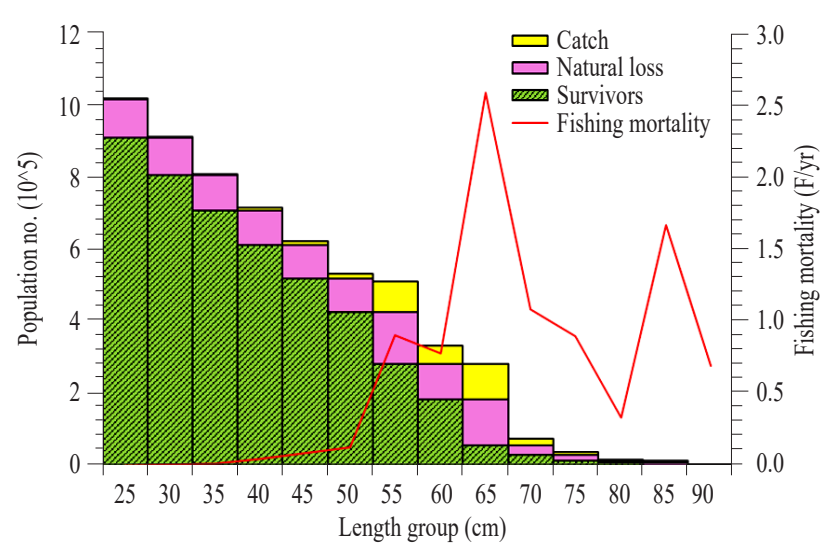

Fig. 8. Length structured cohort analysis of Rhizoprionodon oligolinx

where, $\mathrm{W}$ is weight in $\mathrm{g}$ and TL is total length in $\mathrm{cm}$. Analysis of covariance (ANCOVA) test was performed to check the similarity of regression line between male and female. The slope of the female was found to be significantly $(p<0.05)$ higher in female compared to male whereas, the intercepts of male was found to be significantly $(p<0.05)$ higher than the female. This suggests that the weight of the animals for a particular length varied significantly between males and females. Males tended to be heavier than females till a particular body length (TL) (approximately $60 \mathrm{~cm} \mathrm{TL),} \mathrm{after} \mathrm{which} \mathrm{females} \mathrm{become}$ heavier than males. The relationship between length-body weights for the pooled data is given in Fig. 9 which shows that growth is allometric. Our results are in agreement with earlier reports where males were reported to be heavier than females (Machado et al., 2001; Loefer and Sedberry, 2003; Henderson et al., 2006). Whereas, in females the onset of sexual maturity increases demand of energy for reproduction, such as gonad development, egg formation and gestation which might trigger shifts in the feeding habits (Alonso et al., 2002). To match reproductive energy

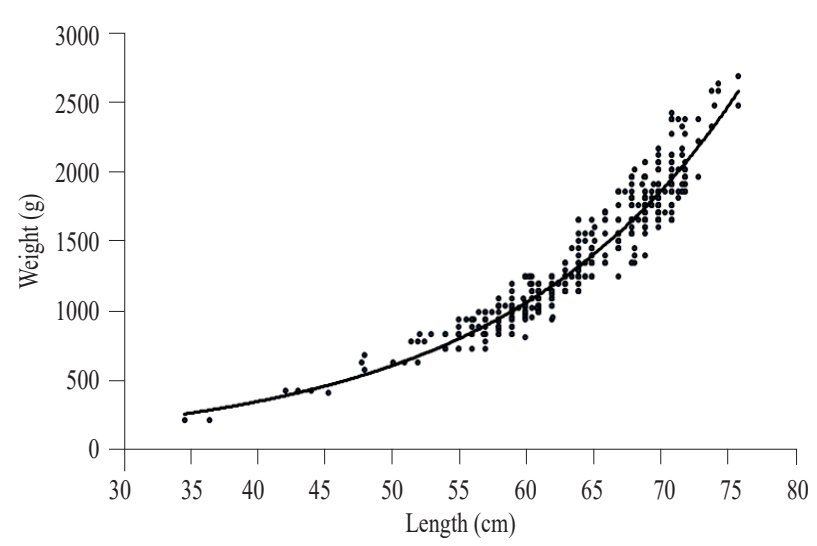

Fig. 9. Length-weight ( $\mathrm{L} v$. W) relationship of Rhizoprionodon oligolinx for both sexes combined 
demand, a quantitative as well as qualitative change in diet may be expected (Fishelson et al., 1987) which possibly affects the body weight of the females.

\section{Maturity, recruitment and gear selectivity}

Mature and pregnant females were recorded throughout the entire fishing period. Maximum percentage of mature and pregnant females was reported during November to April. Maturity study revealed that, female R. oligolinx matured between 60 and $65 \mathrm{~cm}$, with $50 \%$ maturity occurring at $62.3 \mathrm{~cm}$ TL (Fig. 10). Males matured at a lower size range $(55.0-60.0 \mathrm{~cm})$ and $50 \%$ maturity occurred at $59.5 \mathrm{~cm}$ TL (Fig. 11). The annual sex ratio between male and female sharks was 1:1.2.

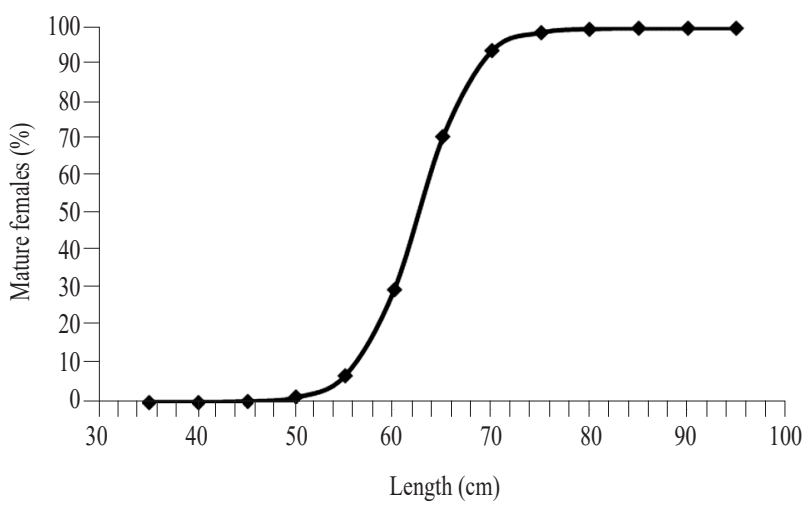

Fig. 10. Estimated length at maturity $\left(\operatorname{Lm}_{50}\right)$ for female Rhizoprionodon oligolinx

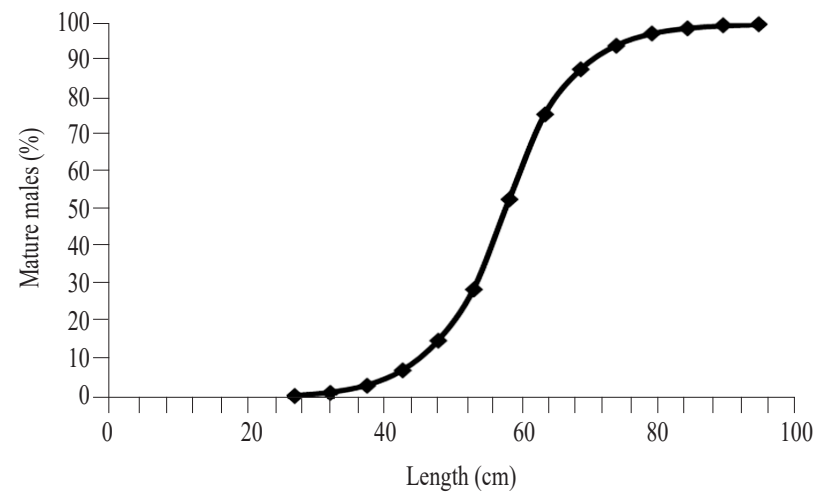

Fig. 11. Estimated length at maturity $\left(\mathrm{Lm}_{50}\right)$ for male Rhizoprionodon oligolinx

The recruitment pattern demonstrated that shark juveniles were recruited in the fishery continuously throughout the year with a peak during the month of April (16.1\%) (Fig.12). The length at recruitment ( $\left.\mathrm{L}_{\mathrm{r}}\right)$ for shark was found to be $30 \mathrm{~cm}$. Logistic regression of the probability of capture for sequential length classes obtained from length converted catch curve analysis revealed that $50 \%$ of the sharks become vulnerable to gear at the total length of $49.7 \mathrm{~cm}\left(\mathrm{~L}_{50}\right)$ (Fig.13).

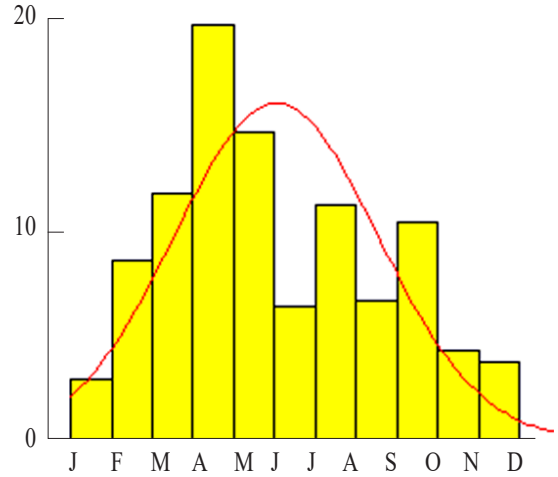

Fig.12. Monthly recruitment pattern of $R$. oligolinx

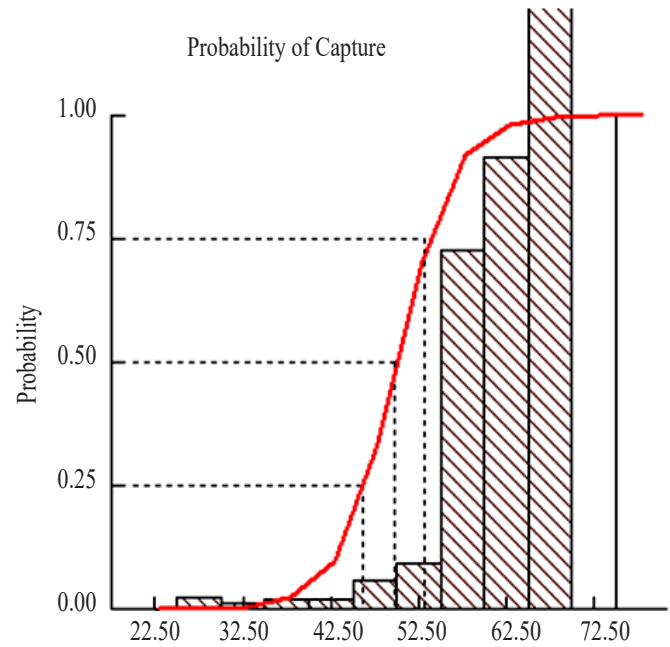

Fig.13. Length at capture $\left(\mathrm{L}_{50}\right)$ of R. oligolinx

The $\mathrm{L}_{25}$ and $\mathrm{L}_{75}$ were also calculated as $46.1 \mathrm{~cm}$ and $53.2 \mathrm{~cm}$ respectively. The $\mathrm{Lm}_{50}$ of males at maturity determined in this study, $59.5 \mathrm{~cm} \mathrm{TL}$, is larger than previously reported for this species. Springer (1964) reported that males matured as small as $38 \mathrm{~cm}$ TL while Appukuttan and Nair (1988) estimated length at maturity of males at $29-38 \mathrm{~cm}$ TL. Males were found to mature at $43-45 \mathrm{~cm} \mathrm{TL}$, with $\mathrm{Lm}_{50}$ at $53.0 \mathrm{~cm}$ in Indonesia (White, 2007), $\mathrm{Lm}_{50}$ at $53.0 \mathrm{~cm}$ TL in Kuwait, (Moore et al., 2012) and $55.0 \mathrm{~cm}$ TL in Bahrain (Moore and Pierce, 2013). In this study, the reproductive load $\left(\mathrm{Lm}_{50} / \mathrm{L}_{\infty}\right)$ ratio was found to be 0.64 . The ratio is comparatively lower than the value of 0.77 suggested by Holden (1974) for elasmobranchs. Similarly, the ratio is also found to be higher than the value of 0.51 suggested by Devaraj (1983) for tropical elasmobranchs. Interestingly, the ratio in the present study is found to be in agreement with the findings of Krishnamoorty and Jagadis (1986) for $R$. acutus from east coast of India and that of Sen et al. (2017) from north-west coast of India. Besides, other 
species in this genus reported so far indicated $\mathrm{Lm}_{50} / \mathrm{L}_{\infty}$ ratio ranging from 0.61 to 0.64 (Springer 1964).

\section{Stock assessment}

The relative $\mathrm{Y} / \mathrm{R}$ and $\mathrm{B} / \mathrm{R}$ analysis of $R$. oligolinx were estimated using selection ogive procedure of FiSAT II (Fig. 14). $\mathrm{L}_{50} / \mathrm{L}_{\infty}$ of 0.471 and $\mathrm{M} / \mathrm{K}$ of 1.725 were used as the input parameter for the analysis. The analysis indicated that, the exploitation rate which maximises yield per recruit $\left(\mathrm{E}_{\max }\right)$ is 0.70 . However, since the analysis does not give any consideration to the biomass, it is advisable to use a considerable safer management reference point (Clark, 1991) such as $E_{0.1}$ which is the level of exploitation at which the marginal increase in yield per recruit reaches $1 / 10$ of the marginal increase computed at a very low value of $E E_{0.1}$ was estimated to be 0.57 . The exploitation level which will

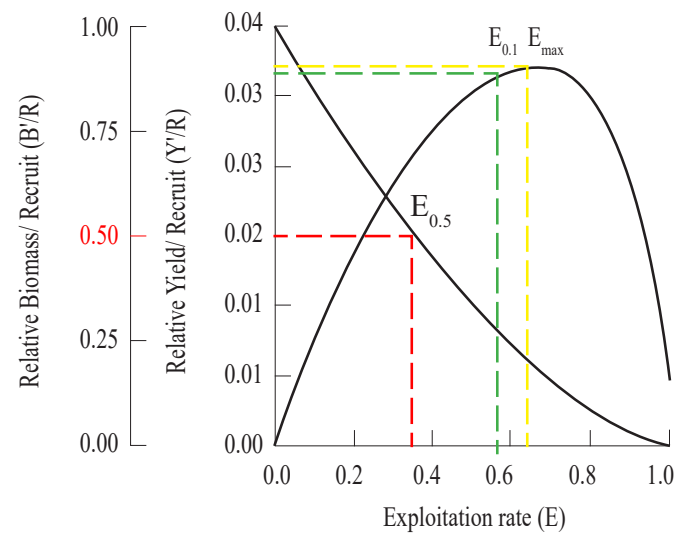

Fig. 14. Stock status of Rhizoprionodon oligolinx using Beverten and Holt's relative $\mathrm{Y} / \mathrm{R}$ analysis from Maharashtra coast

result in the reduction of $\mathrm{B} / \mathrm{R}$ to $50 \%$ compared to virgin biomass $\left(\mathrm{E}_{0.5}\right)$ was 0.35 . Sen et al. (2017) calculated $\mathrm{E}_{\text {cur }}$ as 0.39 , which was found to be very low compared to $\mathrm{E}_{0.1}$ and advised that fishing effort for $R$. acutus can be increased to achieve the target reference point (TRP) in Gujarat waters. However, the increase in fishing effort in the multispecies and multigear regime exists in Gujarat waters would be detrimental for the other commercial important fishery resources in the region (Sen et al., 2017).

While assessing the stock status, it is always advisable to follow some precautionary management reference points such as spawning stock biomass (SSB) to minimise the risk resulted from the uncertainties involved in the assessment of life history parameters due to the inherent limitations and assumptions in assessment methodologies (Rosenberg and Repestro, 1996; Sen et al., 2017). Therefore, Thompson and Bell bio-economic model was used to simulate the impact of fishing on the yield (Y), biomass (B) and spawning stock biomass (SSB) at different fishing levels. The analysis showed that, the present level of fishing has already depleted the virgin stock biomass $\left(\mathrm{B}_{0}\right)$ and spawning stock biomass $\left(\mathrm{SSB}_{0}\right)$ to 32 and 16\% respectively (Fig. 15).

The maximum sustainable yield (MSY) could be obtained by increasing fishing effort by $40 \%$ which will further deplete the $\mathrm{B}_{0}$ and $\mathrm{SSB}_{0}$ to 27 and $10 \%$ respectively that could be dangerous for stock regeneration. On the other hand, the present fishing level needs to be reduced by $20 \%$ to maximise the economic yield (MEY) which will also ensure a SSB level of $22 \%$ that could be comparatively safer for the replenishment of the stock. However, considering the low fecundity of the species, the fishing pressure should be reduced by $40 \%$ to maintain the SSB at a prescribed safe level of $30 \%$ that would ensure the availability of adequate spawners to rebuild the stock for long term sustainability of the resource (Mace and Sissenwine, 1993).

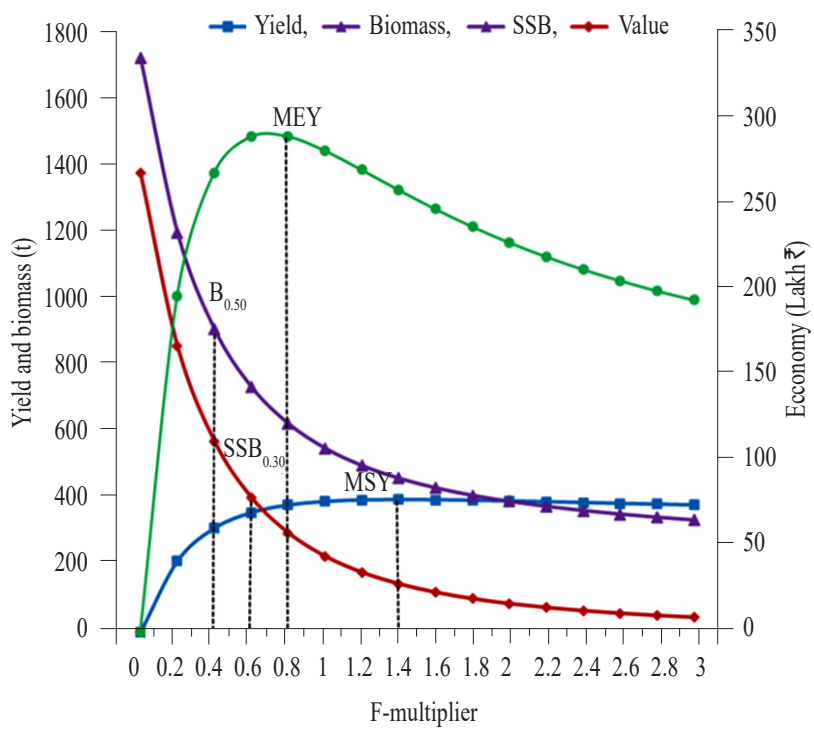

Fig.15. Stock status of $R$. oligolinx using Thompson and Bell analysis from Maharashtra coast

\section{Acknowledgements}

We are grateful to the Director, ICAR-CMFRI, Kochi for the support and facilities provided. We thank the fishers and traders of Satpati, New Ferry Wharf and Sassoon Dock fish landing centre, Palgahar District, Maharashtra for their friendship, cooperation and support.

\section{References}

Alagaraja, K. 1984. Simple methods for estimation of parameters for assessing exploited fish stocks. Indian J. Fish., 31(2): 177-208. 
Alonso, M. K., Crespo, E. A., Garcia, N. A., Pedraza, S. N., Mariotti, P. A. and Mora, N. J. 2002. Fishery and ontogenetic driven changes in the diet of the spiny dogfish Squalus acanthias, in Patagonian waters, Argentina. Environ. Biol. Fishes, 63: 193-202.

Appukuttan, K. K. and Nair, K. P. 1988. Shark resources of India, with notes on biology of a few species. In: Mohan Joseph, M. (Ed.), Proceedings of the First Indian Fisheries Forum, Asian Fisheries Society Indian Branch, Mangalore, Karnataka, India, p. 173-183.

Beverton, R. J. H. and Holt, S. J. 1966. Manuals of methods for fish stock assessment: Part II Tables of yield function. FAO Fish. Biol. Tech. Pap., 38(4), Version 1, Rome, Italy, 67 pp.

Bonfil, R. 1994. Overview of world elasmobranch fisheries, FAO Fish. Tech. Pap., 341: 1-119.

Clark, W. G. 1991. Groundfish exploitation rates based on life history parameters. Can. J. Fish. Aquat. Sci., 48: 734-750.

CMFRI 2013. Annual Report 2012-13. Central Marine Fisheries Research Institute, Kochi, India, 200 pp.

CMFRI 2014. Annual Report 2013-14. Central Marine Fisheries Research Institute, Kochi, India, 274 pp.

CMFRI 2015. Annual Report 2014-15. Central Marine Fisheries Research Institute, Kochi, India, 353 pp.

CMFRI 2016. Annual Report 2015-16. Central Marine Fisheries Research Institute, Kochi, India, 294 pp.

Compagno, L. J. V. 1984. FAO Species catalogue. vol. 4. Sharks of the world: an annotated and illustrated catalogue of shark species know to date. Part 2- Carcharhiniformes. FAO Fish. Synop., 125(4/2): 251-655.

Compagno, L. J. V., Dando, M. and Fowler, S. 2005. A field guide to the sharks of the world. Harper Collins, London.

Devaraj M. 1983. Fish population dynamics: course manuel. CIFE Bull., 3(10): 83 pp.

Ebert, D. A., Smith, W. D. and Cailliet, G. M. 2008. Reproductive biology of two commercially exploited skates, Raja binoculata and $R$. rhina in the western Gulf of Alaska, Fish. Res., 94: 48-57.

Ebert, D. A., Fowler, S. and Compagno, L. J. V. 2013. Sharks of the world. Wild Nature Press, $528 \mathrm{pp}$.

Fishelson, L., Montgomery, W. L. and Myrberg, Jr. A. A. 1987. Biology of surgeonfish Acanthurus nigrofuscus with emphasis on changeover in diet and annual gonadal cycles. Mar. Ecol. Prog. Ser., 39: 37-47.

Froese, R. 2006. Cube law, condition factor and weight-length relationships: history, meta-analysis and recommendations. J. Appl. Ichthyol., 22: 241-253.

Gayanilo, Jr. F. C., Sparre, P. and Pauly, D. 2005. FAO-ICLARM Stock assessment tools II (FiSAT II) user's guide. FAO Computerised information Series (Fisheries), No. 8, Revised version, FAO, Rome, Italy, 126 pp.
Hanfee, F. 1999. Management of shark fisheries in two Indian coastal states: Tamil Nadu and Kerala. FAO Fish. Tech. Pap., 378 Part 1: 1-479.

Hanfee, F. 2001. Trade in whale shark and its products in the coastal state of Gujarat, India. Report to the Rufford Foundation, TRAFFIC India, 38 pp.

Henderson, A. C., Mcllwain, J. L., Al-Oufi, H. S. and Ambu-Ali, A. 2006. Reproductive biology of the milk shark Rhizoprionodon acutus and the bigeye houndshark Iago omanenis in the coastal waters of Oman. J. Fish Biol., 68: 1662-1678.

Holden, M. J. 1974. Problems in the rational exploitation of elasmobranch populations and some suggested solutions. In: Harden-Jones, F. R. (Ed.), Sea fisheries research, John Wiley and Sons, New York, p. 117-137.

Jennings, S., Reynolds, J. D. and Mills, S. C. 1998. Life history correlates of response to fisheries exploration, Proc. R. Soc. Lond. (Biol.), 26: 5333-339.

Krishnamoorty, B. and Jagadish, I. 1986. Biology and population dynamics of grey dog shark, Rhizoprionodon acutus (Ruppell), in Madras waters. Indian J. Fish., 33: 371-385.

Le Cren, E. D. 1951. The length-weight relationship and seasonal cycle in gonad weight and condition in the perch (Perca fluviatilis). J. Anim. Ecol., 20(2): 201-219.

Loefer, J. K. and Sedberry, G. R. 2003. Life history of the Atlantic sharpnose shark (Rhizoprionodon terraenovae) (Richardson, 1836) off the south-eastern United States, Fish. Bull., 101: 75-88.

Mace, P. M. and Sissenwine, M. P. 1993. How much spawning per recruit is enough? In: Smith, S. J., Hunt, J. J. and Revered, D. (Eds.), Risk evaluation and biological reference points for fisheries management. Canadian Special Publication of Fisheries and Aquatic Sciences, National Research Council, Canada, p. 101-118.

Machado, M. R. B., Silva, Z. A. and Castro, A. C. L. 2001. Study of reproductive biology of Rhizoprionodon porosus Poey, 1861 (Condrichthyes: Carcharhinidae) from the continental shelf of Maranhao State, Brazil. Boletim do Laboratório de Hidrobiologia, 13: 51-65.

Moore, A. B. M., McCarthy I. D., Carvalho, G. R. and Peirce, R. 2012. Species, sex, size and male maturity composition of previously unreported elasmobranch landings in Kuwait, Qatar and Abu Dhabi Emirate. J. Fish. Biol., 80(5): 1619-1642. doi:10.1111/j.1095-8649.2011.03210.x.

Moore, A. B. M. and Peircec, R. 2013. Composition of elasmobranch landings in Bahrain. Afr. J. Mar. Sci., 35: $593-596$

Pauly, D. 1983. Some simple methods for the assessment of tropical fish stocks. FAO Fish. Tech. Pap., 243, FAO, Rome, Italy, $52 \mathrm{pp}$.

Pauly, D. and Munro, J. L. 1984. Once more, on the composition of growth in fish and invertebrates. Fishbyte, 2(1): 21. 
Pauly, D. and Caddy, J. F. 1985. A modification of Bhattacharya's method for the analysis of mixtures of normal distributions, FAO Fisheries Circular, 781, FAO, Rome, Italy, 16 pp.

Pauly, D. 1987. A review of the ELEFAN system for analysis of length-frequency data in fish and aquatic invertebrates. ICLARM Conf. Proc., 13: 7-34.

Raje, S. G, Mathew, G., Joshi, K. K., Rekha J. N., Mohanraj, G., Srinath, M., Gomathy, S. and Rudramurthy, N. 2002. Elasmobranch fisheries of India - An appraisal. CMFRI Spl. Pub., 71: 76 pp.

Ricker, W. E. 1975. Computation and interpretation of biological statistics of fish populations. Bull. Fish. Res. Board Can., 191: 382

Rosenberg, A. A. and Repestro, V. R. 1996. Precautionary management reference points and management strategies. FAO Fisheries Technical Paper, 350(2). Precautionary approach to fisheries-Part 2, FAO, Rome, Italy. p. 129-140.

Sen, S., Chakraborty, S. K., Vivekanandan, E., Zacharia, P. U., Shoba, J. K., Jaiswar, A. K., Gyanaranjan, D. and Jayashree, G. 2017. Population dynamics and stock assessment of milk shark, Rhizoprionodon acutus (Ruppel,1837) along Gujarat coast of India. Indian J. Geo-Mar. Sci., 46 (05): 936-946.
Springer, V. G. 1964. A revision of the carcharhinid shark genera Scoliodon, Loxodon and Rhizoprionodon. Proc. U.S. Nat. Mus., 115(3493): 559-632.

Stehmann, M. F. W. 2002. Proposal of a maturity stages scale for oviparous and viviparous cartilaginous fishes (Pisces, Chondrichthyes). Arch. Fish. Mar. Res., 50: 23-48.

Stevens J. D., Bonfil, R., Dulvy N. K. and Walker, P. A. 2000 The effects of fishing on sharks, rays and chimaeras (Chondrichthyans) and the implications for marine ecosystems. ICES Mar. Sci., 57: 476-494.

Thompson, W. F. and Bell, F. H. 1934. Biological statistics of the Pacific halibut fishery. Effect of changes in intensity upon total yield and yield per unit of gear. Rep. Int. Fish. (Pacific halibut) Comm., 8: 49 pp.

Vivekanandan, V. 2001. An Ill-Thought Ban. Samudra 30: 3-9. Available: www.icsf.net/jsp/publication/samudra/ pdf english/issue_30/art01.pdf.

von Bertalanffy, L. 1938. A quantitative theory of organic growth (Inquiries on growth laws II). Hum. Biol., 10: 181-213.

White, W. T. 2007. Aspects of the biology of carcharhiniform sharks in Indonesian waters. J. Mar. Biol. UK, 87: 1269-1276.

Date of Receipt : : 13.02.2017

Date of Acceptance : 14.08 .2017 